\title{
APPROPRIATE INFORMATION SYSTEM IN ROAD FREIGHT TRANSPORT BASED ON THE CARRIERS' REQUIREMENTS AND COSTS
}

The article is focused on the carriers 'requirements and costs of the information systems in road freight transport. Based on the carriers' requirements for information and services as well as the costs of individual information systems, a recommended system or a combination of information systems, which are the most advantageous for carriers, is proposed.

Keywords: Information system, carrier, costs, functions and services.

\section{Introduction}

Individual information systems offer different functions and services to carrying agents for various costs. For the carrier it is, therefore, important whether a concrete information system which he buys, offers the required functions for the reasonable costs. It is important to avoid such situation that the purchased information system often connected with high costs, doesn't meet the carrier's basic requirements and needed functions.

\section{Information systems that can be used by Slovak car- rying agents}

In the Slovak Republic carriers can use navigation and information systems, which are offered by individual vehicle manufacturers or, on the other hand, information systems which are independent from the vehicle mark and are focused on the monitoring of transport and vehicles. There are also information systems that cannot be used by Slovak carriers because they are intended only for selected foreign carrying agents. An example for such an information system is Frotcom, which is focused on the monitoring of vehicles and transport.

\subsection{Information systems offered by vehicle manufacturers}

Information systems (Table 1) that are offered by individual vehicle manufacturers can be classified together with the subsystems for operational control and are designed to monitor operating parameters of vehicles. A part of such subsystem is, for example, fuel management - management and control of the fuel consumption. These information systems also provide carriers with different levels of services which provide a variety of information and can be focused on the vehicle, the driver or the transport management. At each level of service some hardware is needed. It may be a part of the new vehicle or not. Monthly fees are also different according to these levels.

Information systems offered by vehicle manufacturers [1] Table 1

\begin{tabular}{|c|c|}
\hline Vehicle manufacturer & Information system \\
\hline IVECO & BLUE\&MEFleet \\
\hline Mercedes Benz & FleetBoard \\
\hline Volvo & Dynafleet \\
\hline Scania & C200 \\
\hline MAN & Telematics \\
\hline DAF & Infomax \\
\hline Renault & \\
\hline
\end{tabular}

Functions focused on the vehicle

These functions are included in the basic packages of information systems. For their usage there is no need for the purchase of a new hardware for the carrier, because it is already a part of the vehicle (Fig. 1). He pays only a monthly fee that is approximately $15 € /$ month per each vehicle. A carrier therefore obtains the following functions: vehicle journey recording (speed, braking, fuel consumption, and travelled distance), remote data downloading, failures assistance, maintenance planning, log book.

\footnotetext{
* Dusan Halaj, Stefania Semanova

Department of Road and Urban Transport, Faculty of Operation and Economics of Transport and Communications, University of Zilina, Slovakia,

E-mail: dusan.halaj@fpedas.uniza.sk
} 


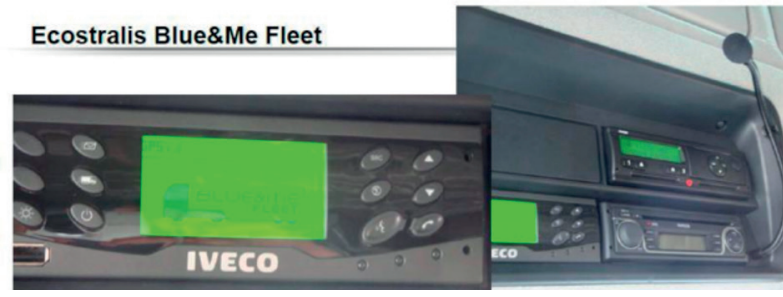

Fig. 1 Hardware IVECO for use of functions focused on the vehicle and driver [2]

\section{Functions focused on the driver}

Functions of this level of information systems are designed not only to monitor the operating parameters of vehicles, but also to control the work of individual drivers. For the usage of these functions, once again, it is not necessary to purchase and procure hardware, because it is also a part of the vehicle. The carrier pays a monthly fee from 25 to $30 € /$ month per each vehicle. Besides the previously mentioned functions he also receives the following functions: time records - all information about the working hours of drivers and the length of their drives, tacho-management remote data downloading from the driver cards and mass memory tachograph.

\section{Functions focused on the transport management}

These functions are not used by Slovak carriers as often as the previous ones because they require to purchase hardware GPS module (Fig. 2) that is not a part of the vehicles and its price including installation is around $2500 €$. The carrier pays for the usage of such functions a monthly fee, which is $35 € /$ month per each vehicle. The carrier receives, in addition to the previously mentioned functions, the following functions and services: processing of messages between the driver and the control centre, on tracks - this function signalizes the dispatcher that the vehicle is close to its final destination, navigation, workflow - this feature integrates data about transport with the navigation, trailer\&refeer - information about trailer temperature, disconnection, connection, geofence - possibility of setting geographical areas including the reporting of exceptions.

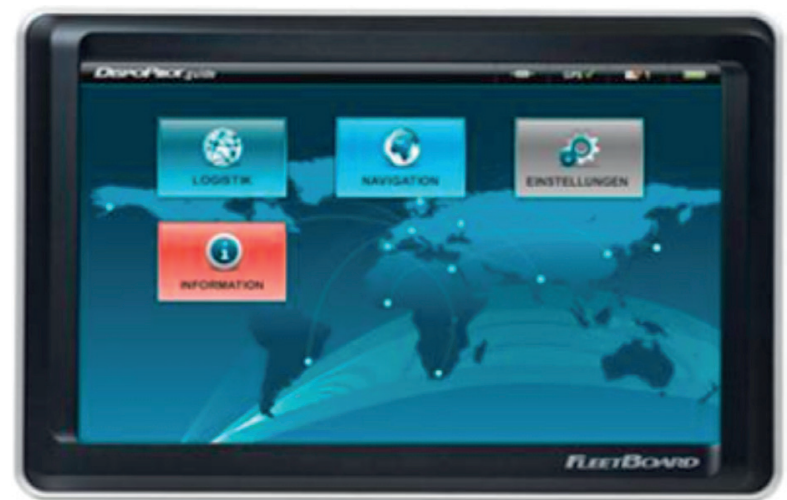

Fig. 2 Hardware Mercedes Benz for use of functions focused on the transport management [3]

\subsection{Information technology for monitoring of transport and vehicles in road transport}

Information technologies for monitoring of transport and vehicles are designed mainly to monitor the vehicle movement, control the work of the drivers, record and monitor the operational status of vehicles. These information technologies, however, do not allow navigation [3]. In the Slovak Republic the carriers can use the following information technologies: Commander, DeMoTech, GENETECH, INFOCAR, TAMEX and EMTEST. In road freight transport, the most widely used system is Commander. For carriers, it offers the following functions and services: on-line monitoring of the vehicles, visualization of the vehicles on the map in the real time, automatic generation of the log book for tax purposes, unlimited storage of the drives history, automatic calculation of the fuel consumption according to data about refuelling, automatic creation of transport orders with their accounting, monitoring of the operational status of the vehicles, the possibility to trace a vehicle after theft, car service management, the ability to track problems on the journey (e.g. congestions, accidents, and etc.) and to inform drivers about the impassable sections, communication with drivers, the possibility of setting alarm when entering restricted areas - waypoint function, simple and accurate report about the service of the vehicle, the possibility to search for stolen vehicles.

In order to use individual levels of services and functions, the carriers need to have a GPS unit installed in their vehicle, which is connected to the bus. The price of this hardware equipment is $547.60 €$ for each vehicle. Its maturity is about 6 years. Besides one-time payment for the purchase, the carriers also pay a monthly fee of $20 €$ per each vehicle.

\subsection{Navigation systems}

Information technologies for the navigation should be distinguished from the information technologies designed for monitoring vehicles and transport. Navigation systems are used to search for the shortest, fastest or the most economical journey of transport from the place of loading to the final destination. Its advantage is mainly navigation of the driver in cities, because the driver can be fully focused on driving and the voice navigation guides him directly to the place of unloading in a concrete area. Navigation manufacturers developed special devices designed for trucks and their price is around $400 €$. Navigation systems also allow receiving actual information about the traffic conditions and in case of impassable sections they can suggest another journey in order to avoid long delays [4].

\section{Transport companies' requirements for various func- tions and information}

The carriers have different requirements for information systems, their functions and services. If the carrier procures some information system, it should meet the most of his requirements 
for its functions and the costs should not be higher than the savings achieved. For carriers it is the most important to know the location of their vehicles during its transport performance. They put on this function even greater emphasis than on the fuel consumption, because in the present competition the utmost importance is put on the customer, delivery deadlines and reduction of empty runs. The fuel consumption is also important because this cost factor builds up to $40 \%$ of all costs. The problem is that the information systems that can be used by carriers in Slovakia do not allow monitoring the fuel consumption on-line. The information system Frotcom enables to monitor the consumption on-line but it cannot be used in the Slovak Republic. Other functions and services that are important for carriers are: warning of the dispatcher when the vehicle is approaching its final destination, information about the drivers working hours, remote data downloading, navigation, which is important mainly to the driver, caution for the dispatcher if the vehicle is deflecting from the journey or approaching the final destination to a mobile phone (smart phone), information about the traffic density and congestions, failure assistance.

Requirements of carriers for information [5]

Table 2

\begin{tabular}{|l|c|c|}
\hline Requirements of carrying agents & Amount & Percentage \\
\hline Actual vehicle location & 58 & 92.06 \\
\hline Fuel consumption - Online & 55 & 87.3 \\
\hline Fuel consumption - Offline & 40 & 63.49 \\
\hline Navigation & 40 & 63.49 \\
\hline $\begin{array}{l}\text { Information about the traffic density } \\
\text { and congestions }\end{array}$ & 35 & 55.56 \\
\hline $\begin{array}{l}\text { Information about the drivers working } \\
\text { hours }\end{array}$ & 28 & 44.44 \\
\hline $\begin{array}{l}\text { Caution when approaching final } \\
\text { destination }\end{array}$ & 15 & 23.81 \\
\hline Information to a mobile phone & 6 & 9.52 \\
\hline Failure assistance & 5 & 7.94 \\
\hline
\end{tabular}

Individual requirements according to their importance are shown in the following Table 2. They are based on the requirements of 63 carriers.

\section{Comparison of costs associated with using information systems}

The carriers use mainly navigation systems that are determined for road freight transport. When the carriers want to optimise their operation, they can procure either information technologies for monitoring transport and vehicles or information technologies focused on the vehicle and the driver in addition to the navigation system. The technologies are offered by individual vehicle manufacturers. For these cases, the costs associated with the use of information systems are determined. The Slovak carriers do not use the functions focused on transport management, because hardware is much more expensive than a navigation device, although, the information systems focused on transport management offer much more functionality.

Costs, which are invested by the carrier into the information system, should not be higher than the savings achieved by the carrier during the utilization of the functions of the information system. Based on average costs shown in Table 3, it is possible to calculate the cost increase in $€ / \mathrm{km}$ and $€ /$ year when using various information systems; the calculation with classification of costs on variable and fixed costs is used [6].

Average costs $€ /$ year a data for the articulated vehicle [7] Table 3

\begin{tabular}{|c|c|}
\hline Fuel costs - 42500 & Other direct costs (ODC) - 5200 \\
\hline Oil costs -800 & \multirow{2}{*}{$\begin{array}{l}\text { Depreciation of vehicle- } 13500 \\
\text { (DoV) }\end{array}$} \\
\hline Tires costs -2500 & \\
\hline $\begin{array}{l}\text { Maintenance, repair and } \\
\text { treatment }(\mathrm{M}, \mathrm{R} \text { and } \mathrm{T})-5950\end{array}$ & Overhead- 7000 \\
\hline Wages with levies - 14000 & Toll - 12000 \\
\hline $\begin{array}{l}\text { Travel compensation (TC) - } \\
7000\end{array}$ & Driving performance - $110000 \mathrm{~km}$ \\
\hline $\begin{array}{l}\text { Heating vehicle costs (HV) } \\
-495\end{array}$ & Time of operation- $3000 \mathrm{~h} /$ year \\
\hline $\begin{array}{l}\text { Coefficient of drives utilization- } \\
0.80\end{array}$ & Technical speed - $55 \mathrm{~km} / \mathrm{h}$ \\
\hline
\end{tabular}

Comparison of the rates when using individual information systems [authors]

Table 4

\begin{tabular}{|c|c|c|c|c|c|c|c|c|}
\hline \multirow[b]{2}{*}{ Rates } & \multicolumn{2}{|c|}{ Navigation } & \multicolumn{2}{|c|}{ Navigation and Commander } & \multicolumn{2}{|c|}{$\begin{array}{l}\text { Navigation+ management } \\
\text { functions of vehicle and driver }\end{array}$} & \multicolumn{2}{|c|}{$\begin{array}{l}\text { Management functions of } \\
\text { vehicle, driver, and transpor }\end{array}$} \\
\hline & $\operatorname{Skm}(€ / \mathrm{km})$ & $\operatorname{Sh}(€ / h)$ & $\operatorname{Skm}(€ / \mathrm{km})$ & $\operatorname{Sh}(€ / h)$ & $\operatorname{Skm}(€ / \mathrm{km})$ & $\operatorname{Sh}(€ / \mathrm{h})$ & $\operatorname{Skm}(€ / \mathrm{km})$ & $\operatorname{Sh}(€ / h)$ \\
\hline Fee & & - & 0.0015 & 0.08 & 0.002 & 0.11 & 0.0025 & 0.14 \\
\hline Hardware & 0.0004 & 0.02 & 0.001 & 0.05 & 0.0004 & 0.02 & 0.0025 & 0.14 \\
\hline Costs & 0.8660 & 15.75 & 0.8680 & 15.86 & 0.8680 & 15.86 & 0.8706 & 16.01 \\
\hline $\begin{array}{l}\text { Cost increase } \\
\text { in } \%(€ / \mathrm{km})\end{array}$ & \multicolumn{2}{|c|}{0.05} & \multicolumn{2}{|c|}{0.28} & \multicolumn{2}{|c|}{0.28} & \multicolumn{2}{|c|}{0.58} \\
\hline $\begin{array}{l}\text { Cost increase } \\
\text { per year }\end{array}$ & \multicolumn{2}{|c|}{$44 € /$ year } & \multicolumn{2}{|c|}{$265 € /$ year } & \multicolumn{2}{|c|}{$265 € /$ year } & \multicolumn{2}{|c|}{$558 € /$ year } \\
\hline
\end{tabular}




\begin{tabular}{|c|c|c|c|c|c|c|c|}
\hline Carrier's requirements & 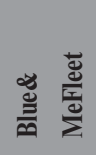 & ปั & 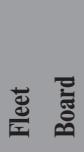 & 衽 & 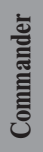 & 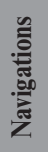 & हี \\
\hline Actual vehicle location & $\mathrm{X}$ & $\mathrm{X}$ & $\mathrm{X}$ & $\mathrm{X}$ & $\mathbf{X}$ & & $\mathrm{X}$ \\
\hline Fuel consumption - online & & & & & & & $\mathrm{X}$ \\
\hline Fuel consumption - offline & $\mathrm{X}$ & $\mathrm{X}$ & $\mathrm{X}$ & $\mathrm{X}$ & $\mathbf{X}$ & & $\mathrm{X}$ \\
\hline Navigation & $\mathrm{X}$ & $\mathrm{X}$ & $\mathrm{X}$ & $\mathrm{X}$ & & $\mathrm{X}$ & \\
\hline Information about the traffic density and congestions & & & & & $\mathbf{X}$ & $\mathbf{X}$ & $\mathrm{X}$ \\
\hline Information about the drivers working hours & $\mathrm{X}$ & $\mathrm{X}$ & $\mathrm{X}$ & $\mathrm{X}$ & $\mathbf{X}$ & & $\mathrm{X}$ \\
\hline Caution when approaching final destination (area) & $\mathrm{X}$ & $\mathrm{X}$ & $\mathrm{X}$ & $\mathrm{X}$ & $\mathbf{X}$ & & $\mathrm{X}$ \\
\hline Information to a mobile phone & & & $\mathrm{X}$ & & & & \\
\hline Failure assistance & $\mathrm{X}$ & $\mathrm{X}$ & $\mathrm{X}$ & $\mathrm{X}$ & & & \\
\hline
\end{tabular}

Table 4 contains the calculated costs in $€ / \mathrm{km}$ and $€ / \mathrm{h}$ of operational downtime (idle time) when the carrier uses information or navigation systems. The rates calculated from the average costs without the use of information systems are 0.8656 $€ / \mathrm{km}$ and $15.73 € / \mathrm{h}$ of operational downtime. These rates may vary depending on the level of costs and vehicle operational data of individual carriers. The rates do not include a profit margin and coefficient of drives utilization.

\section{Conclusion}

Most of the carriers already use navigation and they have it procured before the individual vehicle manufacturers came out with the transport management function. Based on the analysis it can be concluded that in the Slovak Republic there is no information system, which allows on-line monitoring of the fuel consumption. The carriers receive the information whether the journey was in the standard consumption level or above it in certain period after the transportation. Receiving information about vehicles by mobile phone (smart phone) is enabled only $b$ the information system Fleet Board designed for Mercedes Benz trucks. Individual functions and services of information systems required by carriers are shown in the following Table 5. Based on the comparison of functions and costs (Fig. 3), it is possible to recommend obtaining the Commader Information System in addition to the navigation because it provides best balance of functions for carrier and the costs are lower than for a complete package of managerial functions provided by different vehicle manufacturers.

Determination of the costs was based on average costs which arise to the carriers during operating in road freight transport. Costs $€ / \mathrm{km}$ (basic rate $-0.8656 € / \mathrm{km}$ without using any information system) were determined by the calculation with classification of costs on variable and fixed costs. Individual rates may vary according to the amount of individual cost items and operational parameters of carriers. In Fig. 3 we can see the comparison of costs $€ / \mathrm{km}$ when the carriers use only a navigation, navigation and the information system commander, navigation and managerial vehicle and driver functions or complete service of transport management, which also includes navigation. Costs that are connected with the usage of navigation and commander system are comparable with costs of navigation and vehicle and driver managerial functions. In the case of the managerial vehicle and driver functions with navigation, the carrier receives failure assistance service, but he does not get the actual vehicle location function that is much more important.

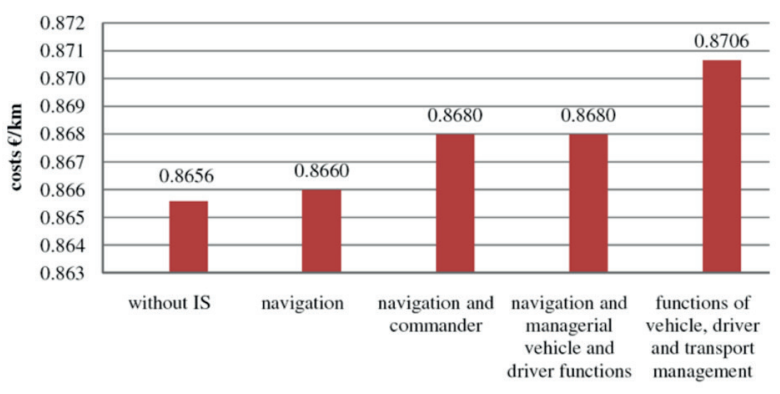

Fig. 3 Costs in $€ / k m$ when using individual information systems [authors]

Based on the costs and carriers' requirements, it can be concluded that the most appropriate combination is to use the navigation and information system Commander, which is designed to monitor vehicles and transport.

The carriers can optimise their operation by using information systems. They can decrease numbers of empty kilometres (increase $\beta$ coefficient) or increase annual driving performance based on acquiring new customers. Table 6 shows about what percentage should be increased $\beta$ coefficient or driving performance to cover costs of IS. A carrier achieves gain of $12980 € /$ year for price of 
Increase of $\beta$ coefficient and driving performance to cover costs on IS [authors]

Table 6

\begin{tabular}{|l|c|c|c|c|c|}
\hline & Without IS & Navigation & $\begin{array}{c}\text { Navigation and } \\
\text { Commander }\end{array}$ & $\begin{array}{c}\text { Navigation+ } \\
\text { management } \\
\text { functions of vehicle } \\
\text { and driver }\end{array}$ & $\begin{array}{c}\text { Management } \\
\text { functions of } \\
\text { vehicle, driver, and } \\
\text { transport }\end{array}$ \\
\hline Rates & Skm $(€ / \mathrm{km})$ & $\mathrm{Skm}(€ / \mathrm{km})$ & $\mathrm{Skm}(€ / \mathrm{km})$ & $\mathrm{Skm}(€ / \mathrm{km})$ & $\mathrm{Skm}(€ / \mathrm{km})$ \\
\hline Without $\beta$ & 0.8656 & 0.8660 & 0.8680 & 0.8680 & 0.8706 \\
\hline With $\beta(0,8)$ & 1.0820 & 1.0825 & 1.0850 & 1.0850 & 1.0882 \\
\hline$\beta$ increase to cover costs of IS & - & 0.8004 & 0.8022 & 0.8022 & 0.8046 \\
\hline $\begin{array}{l}\beta \text { increase to cover costs of } \\
\text { IS in \% }\end{array}$ & - & 0.0462 & 0.2773 & 0.2773 & 0.5777 \\
\hline $\begin{array}{l}\text { Increase of driving } \\
\text { performance to cover cost of IS }\end{array}$ & - & 110468 & 112870 & 112870 & 116100 \\
\hline $\begin{array}{l}\text { Increase of driving } \\
\text { performance to cover cost of } \\
\text { IS in \% }\end{array}$ & - & 0.4255 & 2.6087 & 2.6087 & 5.5456 \\
\hline
\end{tabular}

$1.200 € / \mathrm{km}$, driving performance of $110000 \mathrm{~km} /$ year, and costs without using information systems of $1.0820 € / \mathrm{km}$. For example, if the carrier uses navigation and Commader information system, he must increase driving performance to $112870 \mathrm{~km} / \mathrm{year}$ in order to achieve gain of $12890 € /$ year at an unchanged price.

\section{Acknowledgement}

This paper was developed under the support of project: MS SR VEGA 1/0144/11 Vplyv zmeny kvality poskytovanych sluzieb verejnej hromadnej osobnej dopravy na zvysovanie jej konkurencieschopnosti vo vztahu $\mathrm{k}$ individualnemu motorizmu.

\section{References}

[1] HALAJ, D., POLIAK, M.: Analysis of Selected Information Systems in Road Transport (in Slovak), CMDTUR 2012 : Almanac of papers and posters: the $6^{\text {th }}$ Intern. Scientific Conference, Zilina - Straza, University of Zilina, in EDIS, 2012, ISBN 978-80-554-05124. - S. I-89-I-99.

[2] Internal resources of IVECO Zilina

[3] Internal resources of Mercedes Benz Banska Bystrica

[4] GNAP, J., KONECNY, V., POLIAK, M.: Application of Information Systems in Road Transport (in Slovak), University of Zilina, 2007

[5] HALAJ, D., POLIAK, M., KOLAR, J.: Carrying Agents' Requirements for Information Systems in Road Freight Transport, TRANSCOM $2013: 10^{\text {th }}$ European conference of young research and scientific workers, University of Zilina, 2013, 2013, ISBN 978-80-554-0690-9, pp. 53-56.

[6] GNAP, J.: Calculation of own Costs and Pricing in Road Transport - $3^{\text {rd }}$ edition(in Slovak), University of Zilina, 2006

[7] POLIAK, M., KONECNY, V.: Economy of Road and Urban Transport - Guidelines for Exercises (in Slovak), University of Zilina 2008. 